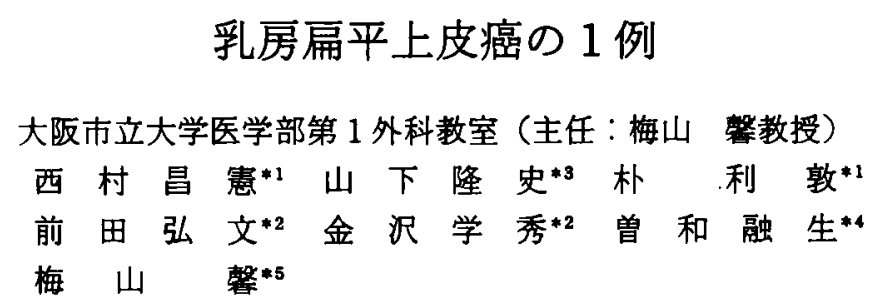

乳腺原発の扁平上皮癌の報告は最近增加の傾向にあるがなお比較的稀である。最近わ れわれは術前の細胞診で扁平上皮癌と診断しえた症例を経験した。

症例は50歳の女性で主訴は左乳房有痛性畽瘤. 近医で乳腺炎の診断にて切開を5けて いた，畽瘤は6 $\times 6.5 \mathrm{~cm}$ で自発痛・腫脹・発赤があり，切開創よりの細胞診で Orange $G$ に好染する大型の細胞を認め, Stage $\mathrm{III}_{\mathrm{a}}$ の左乳腺原発の扁平上皮癌として根治術を施行 した。組織学的には角化傾向の著明な扁平上皮癌で, 腺腔形成はなく PAS 染色, Alcian Blue 染色も陰性であり，pureな扁平上皮癌と思われた。

乳腺原発の扁平上皮癌は腺癌併存例と pure な扁平上皮癌が報告され, 以前は腺癌併 存例の報告が大多数であつたが，最近は pure な扁平上皮癌の報告例も散見され，欧米で はこれらを別個のものとする意見もみられる，最近10年間の本邦での報告例は32例で， 欧米では発生率が報告例によって隔たりがあり，表皮・皮荋付属器由来のるの, epidermoid cyst より発生した畽瘍等が含まれていることが指摘されている. 発生母地は腺癌 併存例では腺癌の扁平上皮化生によると考えられており，pure type では，化生乳管上皮 由来之腺上皮由来と考えられる症例が報告されている。これら扁平上皮癌の臨床症状に は特改はないとされているが，今回調べえた限りでは炎症症状を呈した報告例が 9 例中 4 例 (44.4\%) あり炎症性変化を伴うことがかなりある様に思われる。診断は組織像に よるところが多く, 術前診断では aspiration biopsy, imprint smearによる診断症例が 報告され，その有用性が強調されている，予後については概して他の組織型と変わらな いとする報告が多い様である.

以上乳腺原発の扁平上皮癌症例について報告した。

柬引用語：乳房扁平上皮癌，扁平上皮化生

はじめに

乳腺原発の扁平上皮癌は，本邦では最近 20 年間に 30 余例報告されており，特に最近は増加の傾向にある。 組織学的には腺癌併存例と pure な扁平上皮癌に区別 されているか，このうち pureな扁平上皮癌の報告は 少ない.最近われわれは, 乳腺原発の pure な扁平上皮 癌で術前細胞診で診断しえた症例を経䂆したので若干 の文献的考察を加えて報告する。

1 1 大阪市立大学医学部第 1 外科教室研修医

$\cdot 2$ 同 研究医 $\cdot 3$ 同 助手

*4 同 講師 $* 5$ 同教授

\section{症例}

患者：50歳，女性. 主訴：左乳房有痛性腫瘤。

家族歴・既往歴：特記すべきことなし。

現病歴：昭和58年 6 月, 左乳房に胡桃大の腫瘤を蚛 知するのに気つく７月になって，同部に自発痛・尰 脹・熱感が出現した。そこで9月に近医を受診し，乳 腺炎の診断にて切開を受けるる軽快せず，同月末当科 外来を受診、乳癌の疑いにて入院となった。乳頭より の異常分泌はなかった。初潮は16歳, 妊娠歴 2 回, 出 㕍歴 2 回で，昭和58年 1 月より月経不順を認め，6月 に閉経となった。 
入院時所見：体格栄養中等度. 責血・黄瘟も2られ ない. 全身所見には異常ない，局所所見では左乳房外 下四分円に約 $2.5 \mathrm{~cm}$ の切開創を認め，同部を中心に乳 輪を含めて外上四分円 - 内下四分円に及 $5 * 6 \times 6.5 \mathrm{~cm}$ 大の畽瘤を触知した。腫瘤は弾性硬. 表面は平滑で境 界は比較的明瞭であった．この部を覆ら皮唐に発赤・

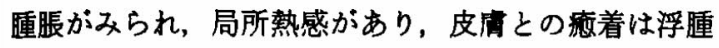
のため不明瞭であった。胸筋との固定はなく乳頭より の異常分泌も認めなかった(図 1). 右乳房には異常所 見は認めなかった。リンパ節は左腋窩に小指頭大以下 のものを数個触知した。

入院時検查成績：血液検査では, 軽度の貧血ならび に核の左方移動を伴った白血球増多がみられる以外異 常を認めず, 肝機能・腎機能その他電解質等は正常で

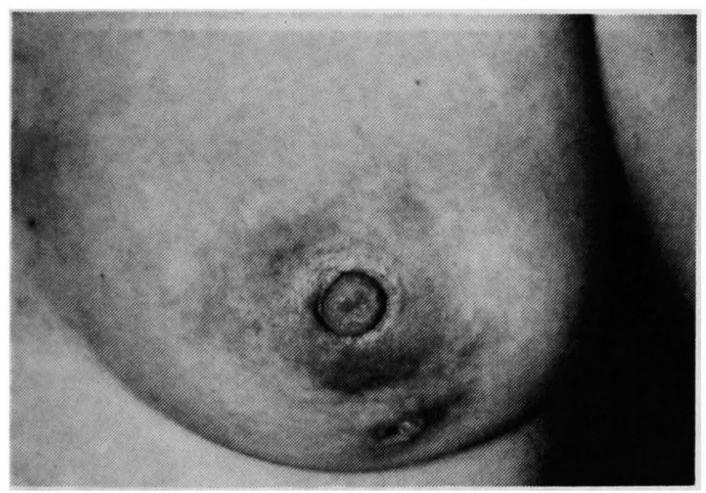

图 1 入院時写真：左乳房外下四分円に切開創を認 め, 腫脹が著明である。
あった（表 1). マンモグラフィー・ゼロラジオグラ フィーでは左乳房に触診部位に一致して, 境界の比較 的明瞭な, 辺縁不整の董瘤陰影を認めた。明らかな石 灰化像は描出されなかった。乳腺超音波検査では, $4.2 \times 2.9 \mathrm{~cm}$ 大の中空像を認め, 辺縁は比較的整, 内部 エコーは均一で，底面エコーの増強がみられ限局型の 細胞成分の豊富な充実性腫湯が考えられた（図 2)。 たェュー上, 左腋窩に $2 \sim 3$ 個のリンバ節腫大が疑わ れた。乳房皮届切開部から約 $2 \mathrm{~cm}$ 深部より擦過細胞診 を施行したところ，Orange Gに染まった大型細胞を 認め, 細胞質の著明な肥厚, 核のクロマチンの増量が みられ，核不整もあり，角化型扁平上皮癌と診断され た(図 3 ). 胸部X線写真, 肝ェコー, 骨シンチでは異 常所見なく，婦人科領域の検索でも異常はみられな

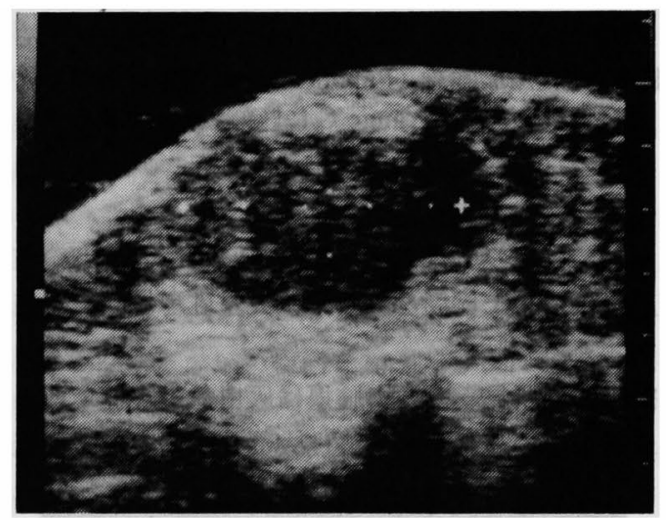

図 2 乳腺超音波像: 内部エコーの均一な腫瘤で $4.2 \times 2.9 \mathrm{~cm}$ の中空像がみられる.

表 1 入院時検查成繶

\begin{tabular}{|c|c|c|c|c|c|}
\hline \multicolumn{2}{|l|}{ 血液検查 } & \multicolumn{2}{|l|}{ 肝機能検査 } & \multicolumn{2}{|l|}{ 血清䉓解質 } \\
\hline $\mathrm{RBC}$ & $354 \times 10^{4} / \mathrm{mm}^{3}$ & T.P & $6.4 \mathrm{~g} / \mathrm{dl}$ & $\mathrm{Na}$ & $142 \mathrm{mEq} / \mathrm{L}$ \\
\hline $\mathrm{Hb}$ & $10.8 \mathrm{~g} / \mathrm{dl}$ & Alb & $3.7 \mathrm{~g} / \mathrm{dl}$ & $\mathrm{K}$ & $4.6 \mathrm{mEq} / \mathrm{L}$ \\
\hline $\mathrm{Ht}$ & $32.2 \%$ & GOT & $14 \mathrm{I} . \mathrm{U}$. & $\mathrm{Cl}$ & $109 \mathrm{mEq} / \mathrm{L}$ \\
\hline WBC & $11700 / \mathrm{mm}^{3}$ & GPT & 17 I.U. & $\mathrm{Ca}$ & $4.1 \mathrm{mEq} / \mathrm{L}$ \\
\hline Bas & 1.0 & $\mathrm{Ch} \cdot \mathrm{E}$ & $0.73 \Delta \mathrm{pH}$ & $\mathrm{P}$ & $3.9 \mathrm{mg} / \mathrm{dl}$ \\
\hline Eos & 2.0 & Al-P & $7.0 \mathrm{KAU}$ & その他 & \\
\hline Meta & 1.0 & $y \cdot \mathrm{GTP}$ & $12 \mathrm{mu} / \mathrm{ml}$ & CRP & $1+$ \\
\hline St & 17.0 & LAP & $9 \mathrm{mu} / \mathrm{ml}$ & ESR & $20 \mathrm{~mm} / \mathrm{hr}$ \\
\hline Seg & 50.0 & LDH & 258WU & & $50 \mathrm{~mm} / 2 \mathrm{hrs}$ \\
\hline Ly & 26.0 & T-cholesterol & $200 \mathrm{mg} / \mathrm{dl}$ & FBS & $87 \mathrm{mg} / \mathrm{dl}$ \\
\hline Mon & 3.0 & $\operatorname{ICG}\left(15^{\prime}\right)$ & $7.5 \%$ & $T \cdot$ Acid P & $2.4 \mathrm{KAU}$ \\
\hline Plateles & $41.0 \times 10^{4} / \mathrm{mm}^{3}$ & 霄機能検査 & & CEA ( $Z$ 法) & $3.6 \mathrm{ng} / \mathrm{ml}$ \\
\hline 出血時間 & 4 分 30 秒 & BUN & $11 \mathrm{mg} / \mathrm{dl}$ & & \\
\hline 频固時間 & 8 分30秒 & creatinine & $0.9 \mathrm{mg} / \mathrm{dl}$ & & \\
\hline & & $\operatorname{PSP}\left(15^{\prime}\right)$ & $30 \%$ & & \\
\hline & & $\left(120^{\prime}\right)$ & $75 \%$ & & \\
\hline
\end{tabular}




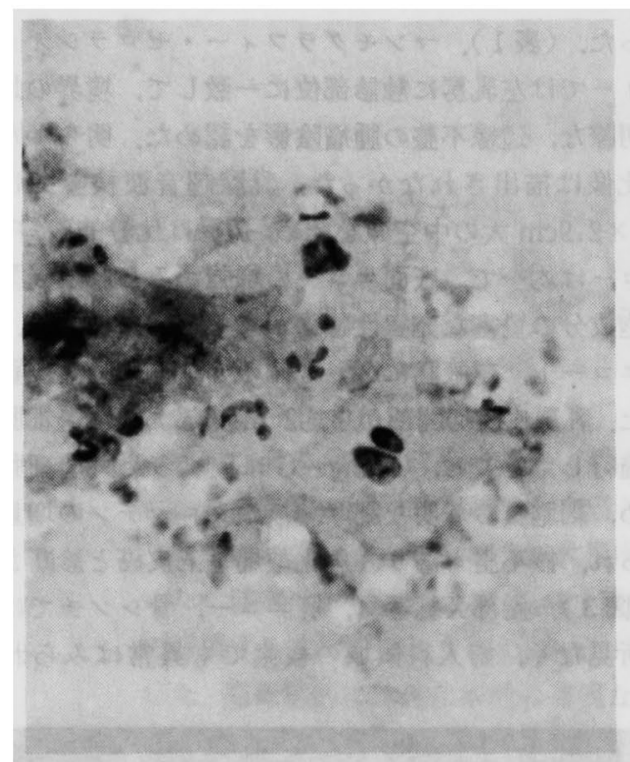

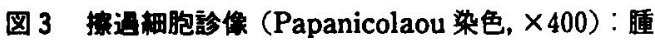
細胞は大きく Orange G K好染し，核不整む著明 であった。

かった。 以上の所見より T3NlbMo, Stage $\mathrm{III}_{a}$ の左乳 腺原発の扁平上皮癌と診断し抬大左乳房切断術を施行 した.

接出标本所見：割面で腫場は戻白色充実性で所々に 出血柴が認められた。畽瘍は大部分周囲組織と明瞭に

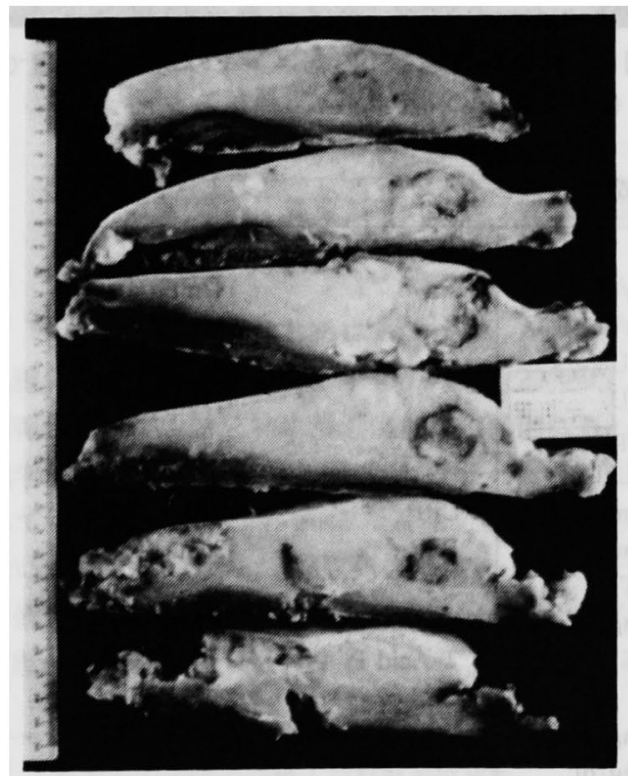

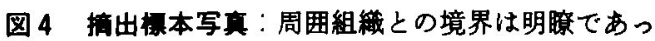
た。内部には所々出血巣がみられた。
区別されていたが，一部境界不鮮明で皮席直下までの 浸潤を思わせる部分も認められた。筇層への浸潤はな かった（図 4 ).

病理組織所見：主病巣は胞巣状構造をとり，中心部 がェオシン好性に染まりいわゆる癌真珠形成を認め, 角化型扁平上皮癌の像を示していた（図 5)，腫漫細胞 は異形性高度で，核の大小不同が著明であり，異常分 裂像も多数みられ，粫湟細胞から变化したと思われる 巨細胞も多く認められた（図 6). 癌胞巣内に明らかな 腺腔形成は観察されず, PAS 染色, Alcian Blue 染色 においても陽性物質はみられなかった。畽瘍間質には 好中球・形質細胞等の炎症性細胞浸潤が著明なところ もみられた，畽湯細胞が一部真皮直下にまで漫閏して いる部分もみられたが，表皮との連続性はなかった。 リンパ節は左腋窩に転移を認めたものの，胸骨傍リン

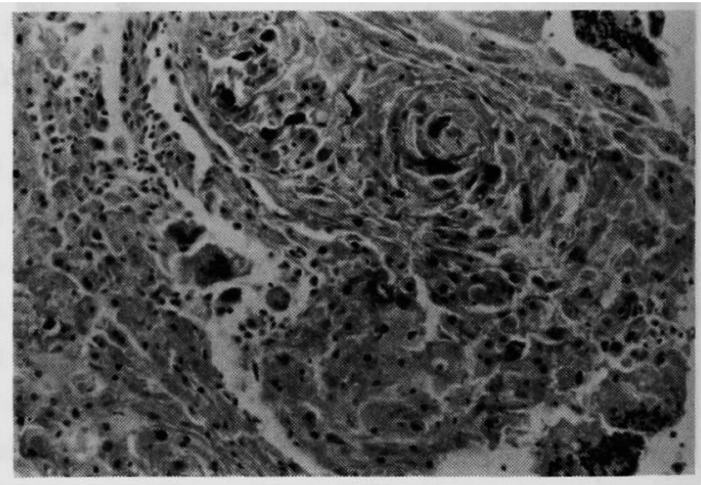

图 5 病理組筬像 (H-E 染色, $\times 200)$ ：癌胞巣中心部 は同心円状棈造を示しエオジン好性で，周辺部には 多核巨細胞もみられたが，腺腔形成はみられなかっ た.

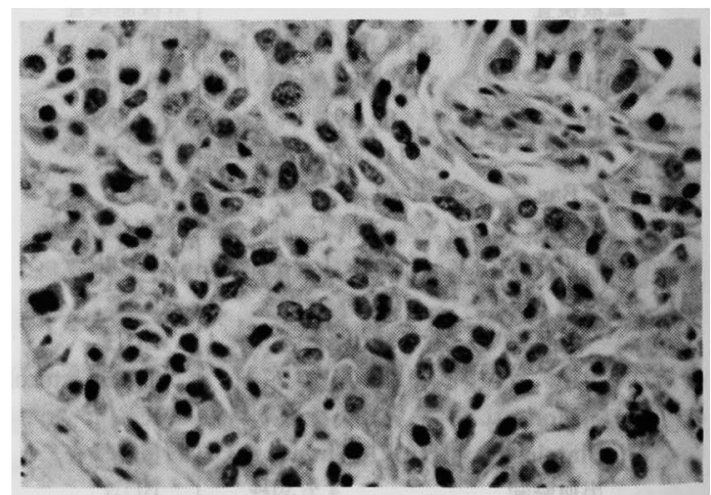

图 6 病理組统像（H-E 染色, $\times 400)$ ：異形性が著明 で，核分裂像す多数みられた。分裂像は癌胞单周辺 部に多く認められた。 


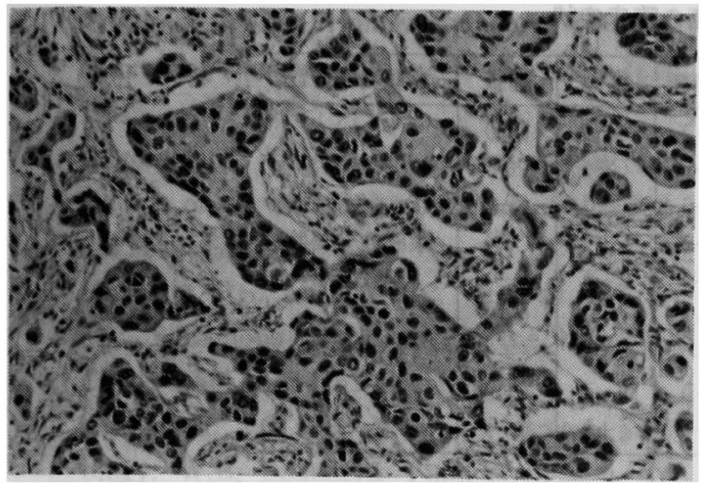

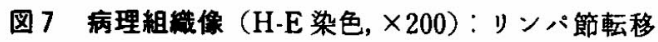
巣では比較的末分化な細胞が敷石状に配列してい た.

公節に転移はなく $\mathrm{n}_{1} \beta$ であった，転移巣は立方状ない し円柱状の癌細胞が大部分を占めていたが，一部に敷 石状構造を示す細胞を認め，胞体は明るく栜細胞に類 似しており，扁平上皮癌細胞と考えられた(図 7)。一 部に腺腔形成を示す部分もみられた。

䤊床経過：術後, 化学療法として5.FU $500 \mathrm{mg}$ を週 2 回投与したが，総投与量 $2,500 \mathrm{mg}$ の時点で白血球減 少を認めた為中止した. 放射線治療として, 鎖骨上部・ 胸骨傍部に45Gray，胸壁・腋窩部に50Gray 照射した。 なお estrogen receptor は, $3 \mathrm{fmol} / \mathrm{mpg}$ 以下であった。 昭和59年10月現在，再発の兆候はみられていない。

\section{考察}

乳腺原発の扁平上皮癌は, pure な扁平上皮癌ならび に腺癌との併存例として報告されているが，乳癌取り 扱い規約1)によると，癌組織の中で明らかな角化傾向 を示す像が大半を占めるものと定められており， pure な扁平上皮癌についての記載はない，欧米でも扁平上 皮癌の報告例は, 以前は大部分腺癌併存例で, 腺癌の squamous metaplasiaによるものとされ2)3, Haagensen`)は1919年から1969年までの50年間に経験 した扁平上皮癌症例20例を集計し報告したが，何れも squamous metaplasia によるもので, pure な扁平上皮 癌は極めて稀としている。しかし最近はArffmann ららにより pureな扁平上皮癌が報告されて以来報告 例が散見されるようになり，Fisher ら ${ }^{6)}$ は扁平上皮化 生巣は扁平上皮癌とは区別すべきであると述へ，欧米 では同様の見解を示す報告が多い,710)

数室で1967年から1983年までの間に経験した乳癌 398 例中扁平上皮癌は 2 例あるが，このうち pure な扁 平上皮癌および腺癌との併存例はそれぞれ 1 例ずつ
で, pure な扁平上皮癌の発生率は全乳癌の $0.25 \%$, 腺 癌併存例を含めると0.5\%であった. UICC 乳癌調查小 委員会による1968年から1975年の8 年間の集計 ${ }^{11}$ で は, 腺澏併存例も含めて7838例中 13 例, $0.17 \%$ あっ たが, pureな扁平上皮癌の集計はない. 最近10年間で われわれが集計しえた本邦例では, 扁平上皮癌は自験 例も含めて 32 例報告されているが，このうち pureな 扁平上皮癌とした報告は，菅野 ${ }^{12)}$, 鳥羽山 ${ }^{13)}$, 松岡 ${ }^{14)}$, 麻賀 ${ }^{15)}$ ら報告にみられるにすぎない. 欧米では pure な扁平上皮癌は全乳癌の $0.1^{77} \sim 0.8^{16)} \%$, 腺癌併存例 を含めて $0.5^{17)} \sim 3.6^{6)} \%$ と報告されている，腺癌併存 例での発生率に若干の差がみられるが，この中には本 邦と異なり併存する腺癌が優位を占めているすの 中618)，あるいは表皮・皮虐付属器由来のるの ${ }^{18)}$, epidermoid cyst より発生した腫瘍 ${ }^{19)}$, 他臟器よりの転 移性腫瘍などが含まれていることが指摘されてい $\Xi^{6) 8)}$.

発生母地：扁平上皮癌と腺癌の併存例では，一般に 腺癌が扁平上皮化生を括こしたものと考えられてい

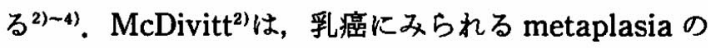
中で squamous metaplasia が最もよくみられる変化 であると述べ, Cornog ら ${ }^{18)}$ は扁平上皮化生の認めら れた乳癌24例について検討を加党，9例に壊死組織や 壊死の結果生じたと思われる品胞に隣接して扁平上皮 化生巣がみられたことから，腫瘍に対するある種の刺 激が扁平上皮の性格をるった細胞増殖を促すのであろ 5 と推論している. 大朏 ${ }^{20)}$, 教室の兽和 ${ }^{21)}$ る, 腺癌と 扁平上皮癌との間に連続的な移行像を認めた症例を報 告している.

一方，pureな扁平上皮癌では，Hasleton"1は腫瘍内 の襄胞壁に腺管上皮，軽度～高度の異形珄を有する扁 平上皮細胞ならびに高分化型扁平上皮癌細胞の間に連 続性を認め，化生乳管上皮より発生したものと推測し

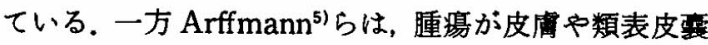
胞と関係のないこと，さらに大乳管も巻き込まれてい ないことから腺上皮由来であるとし，一定の見解はえ られていない.われわれの経験した pureな扁平上皮 癌は，主病巣において角化傾向が著明で腺空形成が観 察されず, PAS 染色, Alcian Blue 染色に拈いても陽 性物質が証明されず，また皮后との連続性がなく， epidermoid cyst 等もみられなかったが, 乳管上皮あ るいは腺上皮由来のいずれかは明らかでなかった。

臨床症状：一般に他の組織型の乳癌と比べて特徴は ないとされているが4)10), 资症症状を呈した扁平上皮 


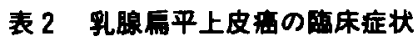

\begin{tabular}{|c|c|c|c|c|c|c|c|c|}
\hline & 赧告 者 & 般告年度 & 年数 & 性 & 自発痛 & 発赤 & 尰脹 & 乳縣異常分泌 \\
\hline 1 & 高 岡 $5^{271}$ & 1974 & 61 & $q$ & $(-)$ & $(-)$ & $(-)$ & $(-)$ \\
\hline 2 & 大 朏 $5^{201}$ & 1974 & 43 & q & $(+)$ & $(-)$ & $(-)$ & ミルク様分泌物 \\
\hline 3 & 曾 和 $5^{211}$ & 1977 & 48 & $q$ & $(-)$ & $(-)$ & $(-)$ & 淡かっ色分泌物 \\
\hline 4 & $5^{28}$ & 1979 & 37 & q & $(+)$ & $(t)$ & $(+)$ & 咏液性分必物 \\
\hline 5 & $"$ & " & 43 & q & $(-)$ & $(-)$ & $(-)$ & 記䇅なし \\
\hline 6 & 鳥羽山ら & 1982 & 54 & 우 & $(+)$ & $(+)$ & $(t)$ & $(-)$ \\
\hline 7 & 佐 藤 $5^{201}$ & 1983 & 56 & f & $(t)$ & $(+)$ & $(+)$ & 污淂分汹物 \\
\hline 8 & 土屋㣌(0) & 1983 & 51 & 우 & $(-)$ & $(-)$ & $(-)$ & $(-)$ \\
\hline 9 & 自 例 & 1984 & 50 & q & $(+)$ & $(+)$ & $(+)$ & $(-)$ \\
\hline
\end{tabular}

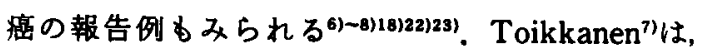
pure な扁平上皮癌 3 例の 5ち 2 例に疼痛, 発赤等の炎 症症状の記戴があり，その組織像で，壊死巣とその結 果生じたと考えられる事胞を認めている，また， Leiman $^{24)}$, Benjamin ${ }^{23)}$, 阿久津 ${ }^{25)}$ らは, aspiration biopsy または imprint smearで好中球・リンハ球等の 炎症性細胞を背景として扁平上皮癌細胞を認めてい る. Fisher ${ }^{6}$ は，腺癌併存例です高頻度に中等度一高度 の壊死を伴ら顕著な細胞反応を有していることが多い と述へてている，今回，文献上症状記载の明らかな8

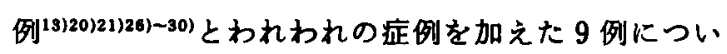
て検討を加えたところ，表 2 に示す如く，自発痛・発 赤・熱感・腫脹等何らかの炎症症状の認められたすの かi 9 例中 4 例 (44.4\%) あり炎症性变化を伴うことも 多い上らに思われる。自験例も近医にて䄻腺资の診断 で切開をらけており，発赤・疼痛・睡脹など炎症症状 を伴っていた。

診断：扁平上皮癌症例で術前診断された報告は少な く，組織像で診断されることが多いが，最近では aspiration biopsyで診断しえた症例が Leiman'”), Trapasso $^{22)}$ ，阿久津 ${ }^{25)}$ ，蔽31らにより報告され， Benjamin $^{231}$ は, biopsy の imprint smear から誛断し, その有用性を強調している. 自検例は前医にて切開を らけており，同部よりの摖過細胞診にて扁平上皮癌と 術前に診断しえた。

治療：手術療法は他の乳癌と何ら变わることなく Stage に応した手街が施行されている。術後の adjubant chemotherapy に関する記載は少ないか，一般 の乳癌症例と同様の治療がなされている。また放射線 治㞠が行なわれた報告すみられる78)18).

予後：報告者により様々で, Toikkanen?), Woodard $^{16)}$ らは予後不良と報告しているが, Haagensen"), Fisher ${ }^{6)} ら の$ 報告の如く, かつていわれ
た程悲覩的なものではなく通常の組織型と変わらない としているものるある. Cornog ${ }^{18)}$ は扁平上皮癌の 5 年 生存率は $50 \%$ で乳癌全体の 5 生率 $48.2 \%$ と有意差を認 めなかったと述べている。 また, Hasleton"144 4 カ月後 に死亡したものから10年生存中のものまで様々である と述べているか，概して通常の組織型と变わらないと している報告が多(、314)6)10)18)24). 自験例は Stage $\mathrm{III}_{\mathrm{a}}$ の 進行癌であり，他院にて，切開をらけていることもあ り蔽重に follow up していく必要があると考えてい 3.

\section{まとめ}

左乳腺に原発し，擦過細胞診にて術前診断しえた pure な扁平上皮癌症例について報告しその発生病理， 臨床像について若干の文献的考察を加えた。

なお本報告の一部は第362回大阪外科集談会で報告した。

\section{文献}

1）乳癌研究会編：臨床・病理乳癌取扱い規約（第 6 版)，金原出版，p. 26， 1982.

2) McDivitt, R., Stewart, F.W. and Berg, J.W.: Tumors of the Breast, in Atlas of Tumor Path. ology. 2nd Series. Armed Forces Institute of Pathology, Washington, D.C., p. 95-96, 1967.

3) Farrand, R., Lavigne, R., Lokich, J., et al.: Epidermoid Carcinoma of the Breast. J. Surg. Oncol., 12 : 207-211, 1979.

4) Haagensen, C.D.: Diseases of the Breast. 2nd edition. W.B. Saunders, Philadelphia, p. 600 $-601,1971$.

5) Arffmann. E. and H $\Phi$ jgaard, K.: Squamous carcinoma of the breast. Path., $90: 319-320$, 1965.

6) Fisher, E.R., Gregorio, R.M., Fisher, B., et al. : The pathology of invasive breast cancer. Cancer, $3: 1-85,1975$. 
7) Toikkanen, S.: Primary squamous cell carcinoma of the breast. Cancer, $48: 1629-1632$, 1981.

8) Bogomoletz, W.V.: Pure squamous cell carcinoma of the breast. Arch. Pathol. Lab. Med., 106 : 57-59, 1982.

9) Hasleton, P.S., Misch, K.A., Vasudev, K.S., et al.: Squamous carcinoma of the breast. J. Clin. Pathol., 31 : 116-124, 1978.

10) Azzopardi, J.G.: Problems in Breast pathology. W.B. Saunders, Philadelphia., p. 297 $-301,1979$.

11）泉婎 腾。遠藤敬一, 久野敬二郎他：UICC 乳癌調 查（TNM 分類）小委員会に上万乳癌全国集計成

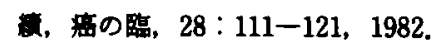

12）管野武, 村上平入郎, 柳田昭一郎他: 扁平上皮乳 滛の 1 症例，神奈川医会誌，2：65，1975.

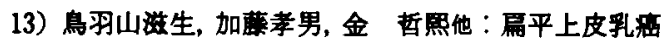
の1 侧, 日臨外会誌, $43: 992,1982$.

14）松岡規男, 䬺田万一，山口正直他：乳层の扁平上皮 莒症例，日臨細胞会誌，18：217，1979。

15）麻賀太郎，岡本 喜，石橋信他：乳腺扁平上皮瘦 の 2 例，神奈川医会誌， $10: 267 ， 1983$.

16) Woodard, B.H., Brinkhous, A.D., McCarty, K. S., et al.: Adenosquamous Differentiation in Mammary Carcinoma. Arch. Pathol. Lab. Med., $104:$ 130-133, 1980.

17) Foot, N.C. and Moore, S.W.: A fatal case of deep seated epidermoid carcinoma of the breast with widespread metastases. Amer. J. Cancer, 34 : 226-233, 1938.

18) Cornog, J.L., Mobini, J., Steiger, E., et al.: Squamous Carcimoma of the Breast. Am. J. Clin. Pathol., 55 : 410-417, 1971.
19) Jones, E.L.: Primary squamous cell carcinoma of brease with pseudosarcomatous stroma. J. Pathol., 97: 383-385, 1969.

20）大朏裕治, 徳毛誠雄, 石合省三：扁平上皮化生をみ 大乳癌の 1 例，外科， $36: 853-855 ， 1974$.

21）曾和融生, 曹 桂植, 松沢 博他：扁平上皮化生を 伴亏乳癌の 1 症例とその文献的考察, 外科診療, $19: 1117-1121,1977$.

22) Trapasso, R.L., McCarty, K.S., Proia, A.D., et al.: Adenosquamous Differentiation: Mammary Needle Aspiration Cytology. Acta. Cytol., 25 : 196-198, 1981.

23) Benjamin, 1.: Imprint smear cytology in the diagnosis of squamous cell carcinoma of the breast. Hum. Pathol., 13 : 1146-1147, 1982.

24) Leiman, G.: Squamous Carcinoma of the Breast, Diagnosis by Aspiration Cytology, Acta. Cytol., $26: 201-209,1982$.

25）阿久津淳子，那頁道世, 神山隆一他：乳腺扁平上皮 癌の一例，日臨紐胞会誌，21:877，1982。

26）桜井立良, 八木正躬, 深井泰俊他：扁平上皮密の 3 例, 日癌治会誌, $9: 69,1974$.

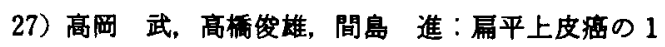
例，日癌治療会誌，9：69，1974.

28）泉春暁，卧井義彦，滝上茂他：乳腺扁平上皮癌 の 2 例，日癌会38回総会記：320，1979.

29）佐藤幹雄，土器辰雄，坚玉好史他：扁平上皮癌を伴 5両側釈癌の 1 例, 癌の臨, $29: 62-65,1983$.

30）土屋真一, 田久保海誉, 中川 他：乳腺原発の扁 平上皮癌の 1 例, 癌の臨, $29: 51-56,1983$.

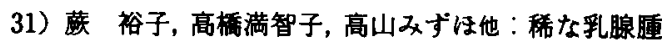
場 3 例の練胞像について, 日臨細胞会誌, $21: 368$, 1982. 


\title{
A CASE OF SQUAMOUS CELL CARCINOMA OF THE BREAST
}

\author{
Masanori NISHIMURA*1), Takafumi YAMASHITA*3), Toshiatsu BOKU ${ }^{* 11}$, Hirofumi MAEDA*1), \\ Gakushu KANAZAWA*2), Michio SOWA*4) and Kaoru UMEYAMA*5)
}

Primary squamous cell carcinoma of the breast is relatively rare, although reports concerning this condition have been increasing recently. The patient was a 50-year-old woman who had a lump with inflammatory change in the left breast. smear cytology of the tumor showed squamous cell carcinoma, and radical mastectomy was performed. Histologically, the tumor was well-keratinized squamous cell carcinoma, with no connection to the skin surface. No evidence of adenocarcinoma was denonstrated by alcian blue or PAS stain. This was interpreted as pure squamous cell carcinoma.

There are two types of primary squamous cell carcinoma of the breast. One is squamous cell carcinoma with adenocarcinoma, and the other is pure squamous cell carcinoma. The former is regarded as squamous metaplasia with adenocarcinoma and the latter as originating in the glandular tissue or metaplastic ductal epithelia of the breast. Clinically, the former type is much more common. In the last 10 years, there have been nine detailed reports of these two types of squamous cell carcinoma in Japan. It is very interesting that, among them, four (44.4\%) had inflammatory change. As for the prognosis, primary squamous cell carcinoma of the breast is much the same as the other carcinomas of this tissue. 